\title{
Financial Performance Analysis of Location, Rental Rate and Parking Revenue on Shopping Centers
}

\author{
Rita Magdalena \\ Brawijaya University Malang \\ tira_occir@yahoo.com
}

\begin{abstract}
This study aims to determine the influence of location, rental rates, as well as parking revenues to the shopping center's financial performance as measured by proxy Return on Investment (ROI) in the city of Surabaya and Sidoarjo. In theory, this study aims to obtain empirical evidence over bid rent theory first proposed by Thünen (1826) and the central location theory proposed by Christaller (1933) so as to benefit the investors, managers, and academics. This study uses secondary data sources. The analysis tool used is regression. Hypothesis testing results show that the strategic location of the shopping center increased financial performance, measured by using a proxy ROI (Return on Investment), while the price of rental and parking revenues shopping center does not have a significant impact on the financial performance. This supported the theory of transaction cost that every financial transaction must consider the cost factor that can lead to lower financial ratios, in addition to the queuing theory, which considers that any value of investment made to reduce queues should consider the return on investment along with factors of customer satisfaction and reducing the volume of the queue. The test results cluster analysis showed that the shopping centers located in residential centers have higher rental rates and earn higher parking revenues when compared with the shopping center located in the downtown area.
\end{abstract}

Keywords: shopping centers, locations, rental rates, parking income, return on investment, financial performance

Abstrak: Penelitian ini bertujuan untuk mengetahui pengaruh faktor lokasi, harga sewa, serta pendapatan parkir terhadap kinerja keuangan pusat perbelanjaan yang berada di wilayah Kota Surabaya dan Sidoarjo. Secara teori penelitian ini bertujuan untuk memperoleh bukti empiris atas teori bid rent yang pertama kali dikemukakan oleh Thunen (1826) dan teori lokasi pusat yang dikemukakan oleh Christaller (1933) sehingga dapat memberi manfaat bagi investor, manajerial, maupun akademisi. Penelitian ini menggunakan sumber data sekunder dan alat analisis yang digunakan adalah regresi. Hasil pengujian hipotesis menunjukkan bahwa semakin strategis lokasi pusat perbelanjaan, maka kinerja keuangan yang diukur dengan menggunakan proksi ROI (Return On Investment) semakin meningkat, sedangkan harga sewa dan pendapatan parkir pusat perbelanjaan tidak memberikan pengaruh signifikan terhadap kinerja keuangan yang didukung teori transaction cost bahwa dalam setiap transaksi keuangan harus memperhatikan faktor biaya yang dapat mengakibatkan penurunan terhadap rasio keuangan, selain itu teori antrian memandang bahwa setiap nilai investasi yang dikeluarkan untuk mengurangi antrian harus mempertimbangkan pengembalian atas investasi tersebut selain faktor kepuasan pelanggan dan mengurangi volume antrian. Hasil pengujian analisis cluster menunjukkan bahwa pusat perbelanjaan yang berada di pusat pemukiman mempunyai harga sewa yang lebih tinggi, dan memperoleh pendapatan parkir yang lebih tinggi bila dibandingkan dengan pusat perbelanjaan yang berada di wilayah pusat kota.

Kata Kunci: pusat perbelanjaan, lokasi, harga sewa, pendapatan parkir, return on investment, kinerja keuangan.

Indonesian economic development from time to time has given a positive direction to the industrial sector of small-scale industries and large-scale industries, both domestic and international. Economic developments seem real in the form of an increasing number of foreign investment in the sector of the property industry in Indonesia. This is indicated by the 
number of buildings - multi-story buildings whose ownership is partly a foreign investment. Similarly, property ownership by foreigners is increasingly facilitated by rights option.

The increase in property development has been faster growing in some large islands of Indonesia such as Sumatra, Java and Kalimantan. The pattern of urban development is expected to be prevalent in some islands in order to improve living conditions and income of local people, many new areas are now emerging with huge potential for targeted investment property industry.

The shopping center has a special attraction for local and international investors to develop a potential new area that is still growing in Indonesia in general and especially in the province of East Java. However, to ensure the viability of a region that can be developed into a business center, there is a need to recognize how much potential can be measured through geographical conditions. Increasing number of new shopping centers that have sprung up that demands companies to compete, sustain, and advance the greater the performance is also marked by the achievement of maximum profit. Therefore, the role of financial reports as information used to diagnose the health of the company is important. One financial analysis tool which can be used as a criterion is return on investment (ROI).

This study aimed to analyze the influence of the location, the price of rental and parking revenue on the financial performance of shopping centers assessed using the method Return on investment (ROI). Financial ratio analysis as an analytical tool in the financial sector has been carried into financial research by researchers such as Yuliati and Utomo (2012), Suharli and Oktorina (2005), as well as Widianti (2015). Research application is still limited with companies engaged on property, especially shopping centers in connection with the influence of external factors such as location and parking revenues.

\section{LITERATURE REVIEW}

Financial performance of an enterprise can be seen and judged from the information presented in the financial statements. The presentation of financial information that contains both quantitative financial position and related changes - the changes and results achieved in the span of a predetermined period so through this information, the health condition of the company can be studied and measured more. Financial Accounting Standards (SAK) state that the financial statements consisting of an income statement, balance sheet and statement of changes in financial position is part of the financial reporting process is complete presentation can be different - different as funds flow statement and statement of cash flows, 
and other reports which is an integral part of the overall financial reporting. In addition, it also includes schedules and their related reports that are as additional information, for example: disclosure of the effect of price changes, financial information from industry and geographic segments (the Indonesian Accountants Association, 2009).

IAI (2009) also revealed that the company's performance measurement can be through the process of analyzing and evaluating financial statements. In predicting the financial position and future performance, financial performance information and financial position in the past are often used as a base. All business transactions all the time either increase or decrease in net economic value are reflected in the financial statements, so the financial statements are the most important media to assess the achievements and the economic condition of a business, which is a condition in which the company has reached a level of efficiency and performance optimal demonstrated by the company's ability to utilize and manage the resources and power of existing funds.

Performance is the result or output of a process (Nurlaila, 2010: 71), while Payaman (2005) assessed the performance as the results achieved on certain tasks that have been implemented. Hunger and Wheelen (2002) states that the measurement of performance depends on an assessment of an organizational unit and the achievement of targets. Goals are set in a strategic stage in the formulation of a strategic management process by taking into account the market share, profitability, and cost reduction of various other sizes. In line with this definition, the financial performance of companies that expressed by Horne et al. (1995) measure the performance of companies based on the profits, which provides an overview of the efficient use of funds by comparing the net income after taxes.

One method used to measure the financial performance of the company is the ROI. By using ROI analysis techniques, the efficiency of the company can be measured in the use of capital, production, and sales of the company not only internally also can be used fatherly compare the performance of companies with similar company if it has a financial data from industry similar.

Prasnanugraha (2007) revealed that one performance measurement that can be used as the information in decision-making is to use the financial statements of a business unit.

Bid rent theory was first proposed by Alonso (1964) and Muth (1969). The models used reveal the relationship between the distances of the city center (CBD) with house prices (Alonso Model). In this model, the rental rate will vary according to the distance to the city center. The farther the distance to the city center, the more expensive due to cost of transportation. The transportation costs incurred replace the rental rate. Measurement of the 
cost of transport is not only calculated on the amount of costs incurred in order to reach the city center, also takes into account the opportunity cost of commuting (the time to relax longer in the office or at home than on the road to the destination, as well as various types of other activities that one could do).

Alonso's bid rent model has three main assumptions: 1). The city is a geographical location within easy reach that is usually located in low-lying areas, not far from a river and hills, 2). The transportation cost is directly proportional to the distance to the city center (CBD), 3). CBD area is the center of business activity that is labor-intensive and distributed in all the central areas of the business. This theory is widely used as an analytical tool in determining the exact location of a business center, which starts with choosing the communities where decisions are made depending on the potential for economic growth, stability, competition and political climate and geographical aspect.

Darin-Drabkin (1977) states that a land has a value and price. Where the value of the land or land value is the value of the land based on the land's ability to provide economic benefits in relation to productivity and economic strategy. The price of land itself is measured by the nominal price of a room for the unit area on the land market. Supply and demand for land greatly affect the market price mechanism. Offer price of land is closely related to soil conditions, comparative advantages such as the location of the level of service, ease of accessibility offered, the development policies of land use plans which are a potential, as well as the physical condition, facilities and land infrastructure. While aspects of land demand is closely related to the financial capacity, the ability to pay for or to buy a piece of land and the physical need for land or space activities in order to perform an activity or specific activity.

Two figures, Retcliff and Alonso (1969), incorporate variable economic approaches to the structure of the zoning of the city, explicitly retail area locations have a tendency to exist in the city center (centralized), a variable ability to pay the rent of land (land value) functions as a base, and distance from city center together can be defined the concept of land-use zone of the city. These form a distribution pattern of urban land that is based on four zones, which originated from the central zone of the city to the zone that is outside the city, namely: residential zone, retail zone, some industrial and transportation facilities zone, and agriculture zone (Yunus, 2004: 68). The greater the degree of accessibility, the greater the benefits to be gained, this is why the retail sector is willing to pay a high rent, because the accessibility factor is intended to attract the attention of the customer (Mustika \& Buchori, 2014). 
Christaller (1933) suggested a basis on positive ground, i.e. ground that supports the city center or any location that can serve the needs of the place. The town center is the center of the existing productive areas due to a variety of important services to be provided land or the surrounding environment. Aulia et al (2009) argued that the Christaller's theory has several principles, namely: Range (distance) is within the range between residents with a place that is the center of activity or market where demand for commodities or goods for sale. For example: if someone wants to buy clothes at the location of a particular market, then the range is the distance that must be taken between the residence with the market or the location where the clothes were sold. The tendency of the population is to look for a variety of goods and services in other markets closer when the ability to reach is small compared to the distance to markets further afield, Threshold (threshold) is the minimum number of residents or consumers needed for the supply of goods or services in question can be continuous for residents or consumers in one space (spatial population distribution).

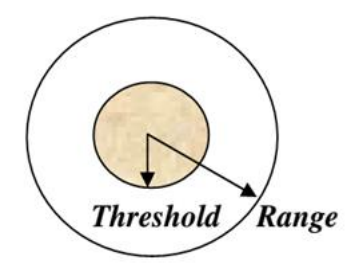

Figure 1. Range and Treshold in Central Place Place Theory by Christaller (1933) in Eppli and Benjamin (1993)

The principle of optimization of the market (market optimizing principle) was born out of the components range and threshold. Based on the assumptions mentioned above from each definition a region is formed that is a region where the center (central place) supplies the demand for goods and services to the surrounding population. And areas that overlap can be formed when a center within range and threshold meets with other central places and form a circle that also has a particular range and threshold. People who stay in areas of overlap relative has the same opportunity to go to two centers. In reality, in selecting a desired commodity or goods, consumers or the public are not always rational.

According to Christaller (1933), there are some obstacles in this theory, namely:

1. Total population.

2. Patterns of accessibility.

3. Distribution.

Ertekin (2008) analyzed the distribution of the shopping center by using the theory of central place in Istanbul. Results from the study showed that the distribution of the 
location of the shopping center is influenced by the level of income as the most dominant factor when compared with the population and accessibility. The main reason for the level of income is a general overview of the capabilities and variations in population patterns of any income group. Shopping centers located near residential areas with high-income residents have greater levels of traffic compared to shopping centers located in neighborhoods with lower income levels.

\section{HYPOTHESIS DEVELOPMENT}

The business strategy of a business depends on the location of the business because location plays an important role as a cost driver. It has the power to make or break a business, because if company or employers have decided and set the location of a business. This will impact fixed costs, which are difficult to reduce. So, selection of a business location should be considered among the marketing strategies that will be used to select consumers. It is important to consider not only the pattern of distribution of the population and per capita income of the local communities, but also to pay attention to the behavior patterns of travel for consumers who are far outside of the central area of the crowds.

The location of the shopping center may affect the sales and profitability of the tenants and also the owner of the shopping center. Because the interests of the tenant and owner or developer with respect to the choice of location may not be a perfect match, bargaining power may come into play. Shopping centers should have the bargaining power necessary to influence the tenants so they can reach the level of target consumers.

As mentioned in the review of research conducted by Darin-Drabkin (1977) a piece of land has a value and price. The value of land or land value is the value of the land based on the land's ability to provide economic benefits in relation to productivity and economic strategy. The concept of time value for money and the factors that affect the value of the investment is characteristic of the economy, so the value of land in an area may increase in value over the long term, while the land treatment when done maturation or development related to the readiness of the resources that the funding (capital owners and the credit of the bank) and labor. Land has physical characteristics that are unique. Land position is a fixed characteristic, for example. Bid rent theory revealed that the closer the distance to the crowded center, the higher the price of the rent. Or in other words that the retail or department stores are willing to pay the largest lease when acquiring locations close to the CBD (Central Business District). Large populations are important for the department store, which requires a large turnover. As a result the tenants are willing and able to pay the high 
rental value of land. Eckert (2015) in his writings realized that the location of the store in the mall can affect sales and profits of the stores and other retailers around, as well as the shopping malls including the owner or developer. Empirically, department stores have a strong value bargaining where, an anchor tenant can determine retail stores which could become "neighbors".

Geographic information system is used to find the appropriate spatial scale for the demographic and economic conditions in each area of a shopping center in each region. Hensher and King (2001) who did a similar study in Sydney found the sensitivity level high enough to affect traffic levels on the shopping center based on parking revenues imposed. Higher parking revenues reduce the level of traffic at the shopping center that otherwise has a good design, though it is not the main cause. Kasuma (2011) states the characteristics of the parking that provide basic services and the assessment of the problems that occur at the site, so it can be seen that the optimal conditions of parking is to provide support to the shopping center in providing services to visitors. Parking conditions are not the main reason for consumers to shop at a particular shopping center. With the increasing number of shopping centers that have sprung up, venues and facilities as well as parking becomes one of the things that centers try to offer to their customers as a comfort.

Based on some of the above phenomenon, it can be hypothesized as follows:

H1: Shopping center locations have a positive effect on the financial performance of the shopping center

$\mathrm{H} 2$ : The rental rate has a positive effect on the financial performance of the shopping center.

H3: Parking revenue has a positive effect on the financial performance of the shopping center.

\section{METHODS}

The research in this study is conclusive or explanatory research. The main purpose is to test a hypothesis or a particular relationship (Singarimbun and Effendi, 1995). The properties of this research study are conclusive, test a relationship or hypothesis, results from research using for decision making, the research are formal, structured, research process, analysis of quantitative data with a large sample, and the basic information required has been prepared.

The nature of this research is the replication of the extension, which will strengthen the degree of reliability of the results of previous studies. This research is to explain and obtain results empirically that the determination of the location, rental rates, and parking revenues assist investors in making investments in shopping centers. 
The population in this study is the overall shopping centers located in East Java with the classification regional shopping center and community shopping center which has 7.500 m 2 - 200,000m 2. Total population of the existing shopping centers in the city of Surabaya and Sidoarjo are 30. They are scattered in several places both strategic as well as being close to populous areas. The study uses nonrandom sample collection method, purposive sampling design. This means that the sample was chosen based on criteria determined by the researcher to represent the population (Sekaran, 2006: 136). The criteria set forth in the sampling of this research are: Shopping center which has an area of $7.500 \mathrm{~m} \mathrm{2-300.000} \mathrm{m} \mathrm{2.} \mathrm{Shopping}$ center located in Surabaya and Sidoarjo with a tenant number no less than 50, Shopping center which has at least 1 department store, Shopping center which has a detailed map showing the location of tenants.

The sampling method used was purposive sampling in this study as well as into the limitations of the research study. Limitations caused by the use of purposive sampling in determining the sample will reduce and enlarge biased generalization of findings generated (Sekaran, 2006: 139). Purposive sampling was selected by the researcher due to the limited amount of data obtained for one of the variables in this study. This research uses data collection method, pooling the data, based on the time the data was collected. According Silalahi (2005: 62) secondary data means data collected comes from second hand sources or from other sources before the research can be done by commenting, interpretation or discussion of original material or discussion of material from the primary data. Data used are data from the Department of Public Works and Human Settlement Spatial, data from the Department of Revenue and Fiscal Management, data from Corporate Financial Statements.

The data collection processes used include several methods such as observation in this study were conducted by direct observation at each business location, whether the business location's relation to infrastructure, the environmental community, the target market, as well as its competitors. In addition, the researcher also observed parking facilities and parking rates at each of the shopping centers and via management, documentation of data was obtained in the form of financial statements or other necessary data for this study, interviews were conducted to obtain data from sources not possible to obtain from written documentation. As well as the researcher conducted an informal question and answer process with informants.

Defining the concept in operation or operation concept (operationalizing the concept) is to explain the characteristics of the object (property) into the elements which can then be observed so the concept can be operationalized in research (Hartono, 2013: 78). Each 
variable in the study should be defined in order to clarify the meaning and measurement. The four variables used in this study consist of three independent variables and the dependent variable. The independent variable location of the shopping center (X1) which is stated that the location starts with selecting the community (Kotler, 2008). Choosing a location for the shopping center that fits perfectly is part of a long-term commitment. The second independent variable is rental rate (X2), the rental rate is the amount of costs to be paid by a company or individual to other parties who have lent something (assets) for a price. In analyzing the return on capital, shopping centers consider several indicators that reflect the cash flow of a plan. The third independent variable is parking revenues (X3), parking is a requirement for vehicle owners and generally preferred if parking is convenient to the venue.

The dependent variable is also called an output variable or consequence. In Indonesia, it is called the dependent variable. The dependent variable is the variable that is influenced by the independent variables. The dependent variable is also called the endogen variable (Sugiyono, 2005). In this study, financial performance (Y) is the dependent variable affected by the location of the shopping center (X1), the rental rate (X2), and parking revenues (X3). Financial performance variables are from company financial statements as found both on the company's website as well as obtained directly from company offices. These financial statements consist of the balance sheet and profit and loss in the period of 5 years. Munawir (2000) revealed that the ROI (return on investment) analysis is one of the various ratios of profitability connected to the company's ability to produce profits through overall funds invested in assets that are used for company operations. ROI, or ROR (rate of return) in the Indonesian language, is a profitability ratio that is used to measure a company's overall funds spent in the assets that were used for the company's operations in order to generate profits. Return on Investment is an analytical tool used in measuring the company's overall ability to generate profits through the assets available within the company. The higher this ratio, the better the state of the company.

ROI can be formulated as follows (Sunardi, 2010):

$$
R O I=\frac{\text { Net profit after taxes }}{\text { Total assets }} \times 100 \%
$$


This study uses data analysis in the form of statistical analysis, descriptive, and inferential statistics. Descriptive statistics were used to describe the data and test the research assumptions, whereas the inferential statistical data analysis techniques were used to measure the presence or absence of similarity between the results obtained from a sample and the results to be obtained from the population as a whole. So, the results obtained from the inferential statistics from samples taken by the researcher can provide generalizations about a population.

Analysis of data using multiple regression ordinary least squares (OLS) using the model as follows: The magnitude of the constants that are reflected in "a" and the regression coefficient of each independent variable indicated by b1, b2 and b3.

\section{RESULTS AND DISCUSSION}

The population in the study are shopping centers in the cities of Surabaya and Sidoarjo which have an area of 7,500 $\mathrm{m} 2$ to $300,000 \mathrm{~m} 2$, which has been in operation and produced financial statements that can be used as an analytical tool both for internal and external interests. The sample selection method used was purposive sampling based on specific criteria that have been established by the researcher. The data used are secondary data obtained from several sources such as the ratio of data (cross-section) were 30 financial stastics of the shopping centers in accordance with the sampling.

Data cross-section is the data collected in a specific time to describe the state or activities at that time (Hendry, 2012). The analysis of statistics results shows that the average rate of return on investment is in the range of $6 \%$ to $10 \%$ per year, the location of the 30 centers on average were near transportation infrastructure which is easily accessible by vehicles, average rental rate of all the shopping centers are in the range 1.000.000 up to $1,500,000$ rupiah per month and the average parking revenue is in the range of 500,001 to 1 billion rupiah.

Based on statistical analysis of the description of each study variable will be displayed as the table below:

Table 5.3 Descriptive Shopping Center Location 2016

\begin{tabular}{lcc}
\hline Criteria & Frequency & Percentage $(\boldsymbol{\%})$ \\
\hline $1=$ Being in Government Center / Office & 0 & 0 \\
2 = Being in the Urban Center & 14 & 46.7 \\
3 = Located Near Transport Infrastructure & 2 & 6.7 \\
$4=$ Being in the Travel Center & 0 & 0 \\
$5=$ Located in Downtown & 14 & 46.7 \\
\hline Total & $\mathbf{3 0}$ & $\mathbf{1 0 0 . 0}$ \\
\hline
\end{tabular}


The table above shows that there are no shopping centers in a central government / central office nor travel center. The majority of the shopping centers are located in city centers and residential centers, each totaling 14 units (46.7\%) while the remaining 2 units (6.7\%) are near transportation infrastructure, namely the Red Bridge Plaza and Mall Pasar Atum.

The location is a place where a business or business activity is done, taking into account factors such as the location relative to urban areas, how to reach and travel time. Details of the shopping centers can be found in appendix 2.

The rental rate is the amount of costs to be paid by a company or individual to other parties who have lent something (assets). Shopping center rental data obtained from the data of Colliers 2016 regarding the existing shopping centers in Surabaya and Sidoarjo are presented in the table in Annex 2. The results of the descriptive statistics of the shopping center rental rate variable are as follows:

Table 5.4 Descriptive rental rate Shopping Center 2016

\begin{tabular}{lcc}
\hline Criteria & Frequency & Percentage (\%) \\
\hline $1=0-149999$ & 0 & 0 \\
$2=150000-299999$ & 8 & 26.7 \\
$3=300000-449999$ & 11 & 36.7 \\
$4=450000-599999$ & 7 & 23.3 \\
$5=\geq 600,000$ & 4 & 13.3 \\
\hline Total & $\mathbf{3 0}$ & $\mathbf{1 0 0 . 0}$ \\
The table above shows that there are no shopping centers that have a rental rate less than Rp. 150,000 per m2 / month. The majority of the \\
shopping centers have the rental rate of Rp. 300000-449999 per m2 / month, 11 units (36.7\%), 8 units (26.7\%) have the shopping center \\
rental rate of Rp. 150000-299999 per m2 / month, and 7 units (23.3\%) have the shopping center rental rate of Rp. 45000-599999 per m2 / \\
month. The remaining 4 (13.3\%) shopping centers have the highest rental rates (more than Rp. 600,000 per m2 / month). They are the Grand \\
City, Pakuwon Supermall Beautiful, Tunjungan Plaza III and IV.
\end{tabular}

Parking is a requirement for vehicle owners. All parking considered was privatelyowned and operated by the private sector. Parking revenue for each shopping center is based on data collected from the Department of Revenue and Fiscal Management as well as from observations and interviews conducted by the researcher. Parking revenue is the income received in a given year and based on the tariff set by the management and manager of shopping centers.

The results of the descriptive statistics of the shopping center parking revenue variable is as follows:

Table 5.5 Revenue descriptive Parking Shopping Center 2016

\begin{tabular}{lll}
\hline Criteria & Frequency & Percentage $(\%)$ \\
\hline $0-500 \mathrm{jt}$ & 8 & 26.7 \\
$501-1 \mathrm{M}$ & 7 & 23.3 \\
$1.001 \mathrm{M}-1.5 \mathrm{M}$ & 10 & 33.3 \\
$1,501 \mathrm{M}-2 \mathrm{M}$ & 1 & 3.3 \\
$>2 \mathrm{M}$ & 4 & 13.3 \\
\hline Total & $\mathbf{3 0}$ & $\mathbf{1 0 0 . 0}$ \\
\hline
\end{tabular}


The above table shows that the majority of the shopping centers have parking revenues amounting to $1,001 \mathrm{M}-1.5 \mathrm{M}$ as many as 10 units (33.3\%), while the shopping center which has the highest parking revenues (> 2M) is Tunjungan Plaza of $13.3 \%$.

Financial performance in this study is measured by ROI measurement with integration capability within the overall profit from the total amounts of assets available within the company. The results of the descriptive statistics of the variables ROI shopping centers are as follows:

Table 5.6 Descriptive ROI Shopping Center 2016

\begin{tabular}{lcc}
\hline Criteria & Frequency & Percentage (\%) \\
\hline$<0$ to $5 \%$ & 20 & 66.7 \\
$6 \%-10 \%$ & 3 & 10.0 \\
$11 \%-15 \%$ & 3 & 10.0 \\
$16 \%-20 \%$ & 1 & 3.3 \\
$>20 \%$ & 3 & 10.0 \\
\hline Total & $\mathbf{3 0}$ & $\mathbf{1 0 0 . 0}$
\end{tabular}

The above table shows that the majority of the shopping centers have a financial performance (ROI) of 0-5\% as many as 20 units (66.7\%), while there is only one shopping center with financial performance (ROI) of 16\% - 20\% (3.3\%), namely Central Point, and 3 units (10\%) have a financial performance (ROI) of more than 20\%: BG Junction, Marina and Lippo Plaza, and Plaza Sidoarjo.

The third hypothesis in this study were tested using multiple regression for each hypothesis is displayed in the table below:

Table 5.11 Hypothesis Test Results

\begin{tabular}{|c|c|c|c|c|}
\hline Model & B & $\mathbf{T}$ & Sig & Information \\
\hline Constant & 2,360 & 2.727 & 0,011 & Significant \\
\hline Locations & 0,375 & 2,605 & 0,015 & Significant \\
\hline Rental rate & -0.224 & $-0,729$ & .472 & Not significant \\
\hline Parking Revenues & --0.448 & -1.844 & 0.077 & Not significant \\
\hline
\end{tabular}

Estimation results using multiple linear regression model. This table presents the results of regression of each insider transactions calculated within 365 calendar days following the transaction date.

The first hypothesis $\left(\mathrm{H}_{1}\right)$ states that the location of the shopping center has positive influence on the financial performance of the shopping center according to ROI. The results of testing the first hypothesis $\left(\mathrm{H}_{1}\right)$ states that the value of the regression coefficient on the variable location is 0.375 . This means that the variable location has a pattern of unidirectional relationship with the financial performance (ROI). As the variable location increases one unit the financial performance will increase by 0.375 assuming variable rental and parking revenues are constant. The T-count value for the variable location is 2.605 with a significance level of less than $5 \%(\mathrm{sig}=0.015)$. This means that the variable locations have a partially significant positive effect on financial performance (ROI).

Thus, a more strategic location of the shopping center, will improve financial performance (ROI) of the shopping center significantly, assuming the variable rental and parking revenues are constant. So, the first hypothesis in this study can be accepted. 
The results of testing this hypothesis are supported by research conducted by Pratiwi (2010); Pratiwi states that the location factor has a positive effect on business success. Similarly, research conducted by Ling Yu (2007) examined more details about the selection of the location of the shopping center using mathematical programming to maximize revenue by taking into account surrounding factors.

The results of testing the first hypothesis also confirm the theories expressed by Christaller (1933) which is further supported by a study conducted by Ertekin (2007). It states that the distribution of the location of the shopping center is based on the ability of residents to shop. So the shopping center located in higher-income locations will be more visited than shopping centers located close to residential areas with lower income levels.

The second hypothesis (H2) states that the rent has positive effect on the financial performance of the shopping center as measured by ROI. The results of testing the second hypothesis $(\mathrm{H} 2)$ state that the value of the regression coefficient on the variable rental charge is -0.224 . That means variable rental rates have the opposite pattern of relationship with financial performance (ROI). When variables rental rates increased one unit the financial performance will declined to 0.224 , assuming a variable location and parking revenues are constant. The T-count value of the variable rental rate is -0.729 with a significance level of more than $5 \%(\operatorname{sig}=0.472)$. So, the rental rate does not have a partially significant effect on financial performance (ROI). Thus, the increase in rental rates or larger shopping centers rental rates, will not have a significant impact on financial performance (ROI) of the shopping center, assuming the location and parking revenue variables are constant. The second hypothesis in this study negatively affects financial performance in the sense that the higher rental rates do not impact the company's financial performance improvement.

Darin - Drabkin (1977) revealed that the high price of the lease of the land based on the land's ability to provide economic benefits in relation to productivity and economic strategy is supported by Alonso's theory (bid rent theory). Although the rent is significant, in life cycle cost (LCC) all the costs of investment have relevance so it is important also to know the condition of the soil and the environment as well in order to take into account the level of investment and expected returns.

The theory of transaction cost proposed by Ronald Coase (1937) in his famous "The nature of the firm" suggests that coordinating the product is highly dependent on the cost (comparative) relative to these two alternatives through market or hierarchy (within the company). The economic theory of transaction costs is an economic theory which analyzes a number of reasons for the existence of the company as well as limitations in the context of 
the market and the organization, and is considered as an alternative to the mechanism of exchange rules (Duran and McNutt, 2010: 756-757; Todeva, 2010: 794).

The economic theory of transactions that have been mentioned above support the results that the second hypothesis is not influential in rental rates and does not significantly influence investment returns as measured by ROI because the company as an entity in this shopping center seeks to avoid the negativity that can be divided into three types (Conner, 1991):

1. The company as an entity seeks to avoid the onset of the high cost of switching in the market.

2. Companies as entities seek to avoid the risks that arise from a number of problems.

3. The company as an entity seeks to avoid relationships in opportunistic markets.

A strategic location can increase rental rates, the company as an entity also must consider the cost factor incurred as part of the company's operations and entities should be entitled risks arising from internal sources and the environment.

The third hypothesis (H3) states that parking revenue has a positive effect on the financial performance of the shopping center which is measured by the ROI and indicated by the value of the regression coefficient on the parking revenue variable, amounting to -0.448 . This means the parking revenue variable has the opposite pattern of relationship with financial performance (ROI), when the parking revenue variable increased one unit the financial performance will decreased by 0.448 , assuming location and rental rate variables are constant. The T-count value of the rental rate variable is -1.844 with a significant level of more than $5 \%(\operatorname{sig}=0.077)$. This means that the parking revenue variable is partially not significant effect on financial performance (ROI).

Thus, the increase in shopping center parking revenues, will not have a significant impact on financial performance (ROI) of the shopping center, assuming a location and rental rate variables are constant. The conclusion is the third hypothesis in this study is not acceptable. The results of this finding are supported by research conducted by Mingardo \& Meerkerk (2012) which revealed that despite favorable parking revenue, the profit margin on shopping center investment was not effected overall. This is not necessarily the same for existing shopping centers in other regions.

In the model of queuing theory which was first disclosed by Erlang (1913) queue arises because existing facilities and services are not able to meet the needs of service, so users have to wait for some time for services. Therefore, a business may choose to provide additional facilities aimed at reducing or preventing their queue. These can be assessed in terms of the 
cost to provide additional services to accommodate the queues reducing the company's profits to below the acceptable level of profit. On the other hand, the increasing length of the queue may result in customers and clients choosing other places that provide better service facilities. In connection with this research, it does not affect the significance of parking revenues due to the fulfillment of customer satisfaction with the parking facilities. The shopping center's main purpose of operating is leasing the building to the tenants to provide facilities as a supporting factors.

\section{CONCLUSIONS}

Shopping centers very flourishing in the country in recent years, especially in big cities, so the researcher examined the topic of shopping centers using ROI as a measure of financial performance via the variable measurements locations, rental rates, and parking revenues. Based on the analysis performed and the results obtained the following was concluded:

1. Improving the location or choosing a more strategic location of the shopping center will improve financial performance (ROI) significantly, so the first hypothesis in this study can be accepted.

2. The increase in rental rates or the larger shopping centers rental rates, will not significantly impact the decline in financial performance (ROI) of the shopping center, so the second hypothesis in this study cannot be accepted.

3. The increase in shopping center parking revenues, will not significantly impact the decline in financial performance (ROI) of the shopping center, so the third hypothesis in this study cannot be accepted.

4. Cluster grouping indicates that the shopping centers located in residential areas have rental rates relatively higher than in other areas, and the revenue generated from parking is also higher than by the shopping centers located outside residential areas.

\section{REFERENCES}

Alonso W. (1964). Location and Land Use: Toward a General Theory of Land Rent. Harvard University Press, and Cambridge.

Abubakar, I. (1998). Guidelines for Planning and Operation of parking revenues, the Directorate of Traffic and Transportation Systems Directorate General of Land Transportation Kota, Jakarta. 
Aulia, A., AM Elmanisa, MP Gunawan. (2009). Spatial distribution patterns Minimarket in Small Cities. Journal of Urban and Regional Planning, Vol. 20 No. 2, August 2009, p. 78-94.

Christaller, W. (1933). Central Places in Southern Germany (translated by Baskin C (1966)). Prentice-Hall, Englewood Cliffs, NJ.

Darin-Drabkin, H. (1977). Land Policy and Urban Growth. United Kingdom: Pergamon Press.

Eckert, A, H. Zhen, SW Douglas. (2015). An empirical analysis of patterns tenant location near department stores in planned regional shopping centers. Journal of Retailing and Consumer Services. 22 (2015): 61-70.

Ghozali., I. (2009). Applications Multivariate with SPSS Program. Agency Publisher Diponegoro University Semarang

Hendry. 2012. Types and Data Types. Http://teorionline.net/jenis-dan-tipe-data.html. 23 September 2012.

Horne, Van JC, Wachowichz JR, JM (1995). Fundamentals of Financial Management, $9^{\text {th }}$ Edition. Prentice Hall International, Inc.

Hunger, J. D., \& Thomas, LW. (2002). Strategic Management. Ed 2. Andi. Yogyakarta

Husaini Usman. (2006). Pengantar Statistika. Jakarta: PT Bumi Aksara.

Ikatan Akuntan Indonesia. (2009). Standar Akuntansi Keuangan. Penerbit Salemba Empat, Jakarta.

Kasuma, IGN. (2011). Financial Feasibility Analysis Development Plan Parking Building Storey Market Lokitasari, Thesis. Udayana University, Denpasar.

Mingardo, G \& Meerkerk, JV. (2012). Is parking supply is related to the turnover of shopping areas? The case of the Netherlands. Journal of Retailing and Consumer Services. 19 (2012): 195-201.

Munawir. (2000). Financial Statement Analysis, 4th Edition, Liberty, Yogyakarta.

Muth, RF. (1969). Cities and Housing: The Spatial Pattern of Urban Residential Land Use, Third Series: Studies in Business and Society, University of Chicago Press, Chicago.

Mustika, R \& Buchori, I. (2014). Comparison of Characteristics of Modern Large-Scale Retail Visitor Center and Suburbs Semarang. Journal PWK Engineering, Vol. 3 No. 4. 2014.

Nielsen. (2014). It's All at the mall: Consumers Look to Shopping Centers as Community Centers.www.nielsen.com / us / en / insights / news / 2014 / its-all-at-the-mallconsumers-look-to-shopping -centers-as-community-centers.html. 10 April 2015.

Nurlaila. (2010). Human Resources Management. I. Publisher LepKhair.

Prasnanugraha, P. (2007). Influence Analysis Ratio - the ratio of Financial Performance against Commercial Banks in Indonesia (Empirical Study of Banks - Commercial Banks Operating in Indonesia). Thesis Graduate Program Master of Science in Accounting (unpublished)

Pratiwi, A. (2010). Analysis of Factors Affecting Site Selection To Success Services Business (Study on Service Business Micro Small-Around Campus Undip Pleburan).Essay.

Sawir, A. (2003). Analisis financial performance and corporate financial planning ". Jakarta: PT Gramedia main library.

Silalahi, U. (2005). Social Research Methods. Bandung: Unpar Press.

Sunardi, H. (2010). Effect of Performance Appraisal with ROI and EVA to Return Shares in the Company Incorporated in LQ 45 index in the Indonesia Stock Exchange. Journal of Accounting, Vol.2 No.1. 2010: 70-92.

Suharli, M \& Oktorina, M. (2005). Predicting Return on Investment in Equity Securities through Ratios Profitability, Liquidity, Debt and Public Enterprises in Jakarta. SNA VIII Solo, 15 to 16 September, 2005. 
Sugiyono. (2005). Methods of Research Administration. Bandung: Alfabeta.

Widianti, H. (2015). Analysis of Return on Investment (ROI) for Measuring Effectiveness Performance (Case Study at PT. Aesthetics Island Mas Tegal). Journal of Accounting and Finance. Vol. 2 No. 1. March 2015.

Yuliati, T \& Utomo, H. (2012). Effect of Infrastructure Proximity, Proximity Consumer, Cost to Income Dealer Location in Areal Route Southern Trails Salatiga. Journal Among Makarti. Vol 5 No. 10. December 2012.

Yunus, H. S. (2004). The spatial structure of the city. Yogyakarta: Student Library. 